\title{
RANCANG BANGUN SISTEM INFORMASI EKSEKUTIF PERPUSTAKAAN
}

\author{
Shanty Karina \\ 175100051 \\ Universitas Mitra Indonesia, Sistem Informasi \\ santykarina.student@umitra.ac.id
}

\begin{abstract}
ABSTRAK
Perpustakaan yang baik memiliki sistem yang baik. Para eksekutif, dalam hal ini kepala perpustakaan harusnya bisa memanfaatkan kemajuan teknologi untuk mempermudah kinerjanya untuk kemajuan perpustakaan itu sendiri.

Permasalahan yang dihadapi adalah banyaknya data yang terdapat didalam database, sehingga memerlukan waktu yang cukup lama untuk membuat keputusan dari data yang ada tersebut.

Perancangan sistem informasi eksekutif ini dikembangkan menggunakan bahasa pemrograman Visual Basic dan diintegrasikan dengan database SQL Server. Dengan adanya sistem informasi eksekutif, diharapkan tugas kepala perpustakaan dapat terbantu.
\end{abstract}

Kata kunci: Sistem Informasi Eksekutif, Perpustakaan

\section{A. PENDAHULUAN}

Database atau basis data adalah kumpulan data yang disimpan secara sistematis di dalam komputer yang dapat diolah atau dimanipulasi menggunakan perangkat lunak (program aplikasi) untuk menghasilkan informasi. Pendefinisian basis data meliputi spesifikasi berupa tipe data, struktur data dan juga batasanbatasan data yang akan disimpan.

Proses memasukkan dan mengambil data ke dan dari media penyimpanan data memerlukan perangkat lunak yang disebut dengan sistem manajemen basis data (database management system | DBMS). DBMS merupakan sistem perangkat lunak yang memungkinkan pengguna database (database user) untuk memelihara, mengontrol dan mengakses data secara praktis dan efisien. Dengan kata lain semua akses ke basis data akan ditangani oleh DBMS. Ada beberapa fungsi yang harus ditangani DBMS yaitu mengolah pendefinisian data, menangani permintaan pemakai untuk mengakses data, memeriksa sekuriti dan integriti data yang didefinisikan oleh DBA (Database Administrator), menangani kegagalan dalam pengaksesan data yang disebabkan oleh kerusakan sistem maupun disk dan menangani unjuk kerja semua fungsi secara efisien. Program yang dapat digunakan untuk menggunakan basisdata adalah MS Access dan MySql. Ada juga oracle untuk basis data skala besar. 


\section{B. TINJAUAN PUSTAKA}

PUTRA, Arie Setya; FEBRIANI, Ochi

Marshella. Knowledge Management

Online Application in PDAM Lampung

Province. In: Prosiding International

\section{STUDI KASUS}

Sistem database untuk perpustakaan ini sangat diperlukan karena untuk mengefisiensikan waktu dan menghemat

Saya sudah melakukan diskusi pada masyarakat sekitar dan memang benar dengan adanya database dalam sistem jaringan perpustakaan sangat membantu mereka dalam mempersingkat waktu tetapi

\section{E. KESIMPULAN}

Dari penjelasan artikel yang saya buat di atas dapat disimpulkan bahwa dengan adanya database dalam sistem jaringan perpustakaan sangat membantu dalam mempermudah kinerja untuk kemajuan perpustakaan itu

\section{A. REFRENSI}

[1] PUTRA, Arie Setya; FEBRIANI, Ochi Marshella. Knowledge

Management Online Application in

PDAM Lampung Province. In:

Prosiding International conference on

Information Technology and Business

(ICITB). 2018. P. 181-187.

[2] FEBRIANI, Ochi Marshella; PUTRA, Arie Setya. Sistem Informasi

Monitoring Inventori Barang Pada conference on Information Technology and Business (ICITB). 2018. P. 181-187

biaya untuk membeli kertas, dan saya sudah mecoba mengaplikasikannya ke beberapa perpustakaan.

\section{DISKUSI}

mereka masih binggung cara menggunakannya karena sudah terbiasa dengan cara yang manual dan bisa jadi membutuhkan waktu yang lama untuk menyesuaikannya.

sendiri. Tetapi masih butuh penyesuaian bagi sebagian penjaga perpustakaan karena mereka sudah terbiasa dengan cara yang manual.

Balai Riset Standardisasi Industri

Bandar Lampung. Jurnal Informatika, 2014, 13.1: 90-98

[3] Putra, A. S. (2018, July 9). 2018

Artikel Struktur Data, Audit dan Jaringan Komputer. Retrieved from osf.io/3uq8w 